\title{
Vulnerability factor in earthquake risk assessment model for roads in Indonesia
}

\author{
Mona Foralisa Toyfur ${ }^{1, *}$, Krishna S. Pribadi ${ }^{2}$, Sony S. Wibowo ${ }^{2}$, and I Wayan Sengara ${ }^{2}$ \\ ${ }^{1}$ Civil Engineering, Faculty of Engineering, Sriwijaya University, Jl. Raya Palembang Prabumulih Km 32, Inderalaya, 30662 , \\ Indonesia \\ ${ }^{2}$ Civil Engineering, Faculty of Civil and Environment, Bandung Institute of Technology, Jl. Ganesha no 10, Bandung, 40132, \\ Indonesia
}

\begin{abstract}
Indonesia is one of the prone countries to natural disasters. The road is one of the infrastructures affected by the disaster. Natural disasters that contribute to road damages are earthquakes, landslides, and floods. One of the factors affecting disaster risk is a vulnerability. The higher the vulnerability, the possibility of damage and loss will be higher. Vulnerability indicators for roads will be assessed in this study. The Earthquake Disaster Risk Index is adopted in this study. The physical and economic vulnerability are the factor components that identified in this study. Indicators are selected by valid, reliable, data availability, objective, quantified, and directly influence the risk. The indicators are analyzed using Analysis Hierarchy Process in order to get the weight. There are 9 (nine) indicators selected as part of physical vulnerability.
\end{abstract}

\section{Introduction}

Infrastructure is a construction that supports community activities. In the event of a disaster, infrastructure is one of the elements affected by the disaster. One of the infrastructures that were affected by the disaster and caused a lot of influence on community activities is the roads.

In the last twelve years recorded several major earthquake activities in Indonesia, the Aceh earthquake accompanied by the tsunami at the end of $2004(\mathrm{Mw}=$ $9.2)$, the 2005 Nias earthquake $(\mathrm{Mw}=8.7)$, Yogya earthquake of $2006(\mathrm{Mw}=6,3)$, Tasik earthquake 2009 $(\mathrm{Mw}=7.4)$, Padang earthquake of $2009(\mathrm{Mw}=7.6)$. The last major quake was the Central Aceh earthquake in $2013(\mathrm{Mw}=6.0)$, and the Pidie earthquake of $2016(\mathrm{Mw}$ $=6.5)$. The earthquakes have caused damages to building, houses, and infrastructures.

Roads play an important role in the movement and development of one region. If the function of one road segment is disturbed, then other road segments located on the road network will be disrupted.

According to the Damage and Loss Report on the West Sumatra earthquake in 2009, damage and losses on road and bridge sector resulted in a loss of $\mathrm{Rp} 303.1$ billion. Damage to road and bridge infrastructure is caused by longitudinal cracks.

When the Pidie earthquake (2016) occurred, longitudinal and transversal cracks damage on Pidie Jaya / Pidie - Meureudu and Meureudu- Batas Pidie Jaya / Bireun roads (Fig. 1) [1]. The estimation of damage cost Rp 30 billion for repairs.

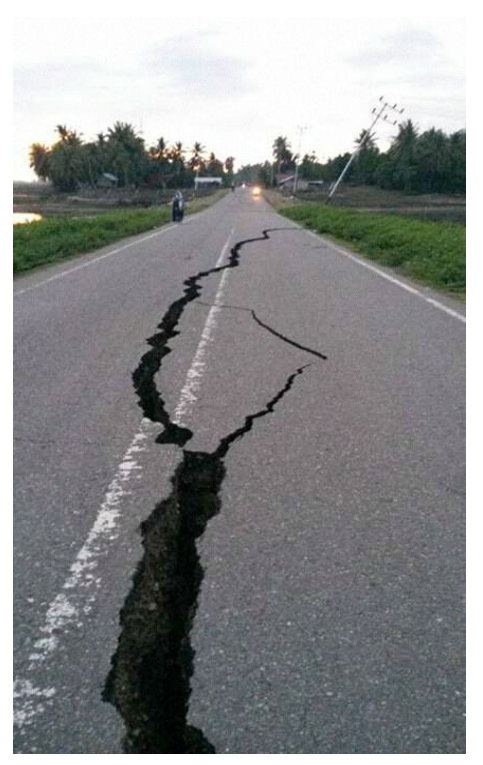

Fig. 1. Longitudinal crack caused by Pidie's earthquake 2016.

The existence of near-fault effects located near the road increases physical damages to roads and bridges. In the occurrence of the earthquake of Central Aceh (2013) and Pidie Jaya (2016) damage to roads and other buildings affected by the Samalanga-Sipopok fault.

Although floods are the most frequent disasters, earthquakes are the most damaging disasters. earthquakes can trigger other disasters such as landslides, liquefaction, and tsunamis. 
Reference [2] describes the disaster in the Pressure and Release (PAR) model. The model explains that disasters can occur from interactions between vulnerabilities and hazards. the progression of vulnerability consists of underlying causes, dynamic pressures, and unsafe conditions. Vulnerability will be catastrophic in case of a hazard event.

The vulnerability is a characteristic and condition of a community, system or asset that makes it likely to be affected by the harmful effects of hazard [3]. According to Reference [4], vulnerability is a measure of the degree of inclination of an object, region, individual, group, community, state or other entity exposed to the consequences of earthquake hazards. This measure is derived from a combination of physical, social, economic and environmental factors or processes. In addition, according to Reference [5], vulnerability is defined as the level of loss in risky elements resulting from certain hazard levels. The vulnerability of an element is depicted in the ratio of the expected loss to the maximum possible loss of a scale of 0 to 1 or 0 to $100 \%$.

The vulnerability can be reduced through actions that have a low tendency to cause harm. Following the guidelines for planning the infrastructure can reduce the risk of disaster damage. In addition, retrofitting can reduce the vulnerability of construction from hazards and reduce the risk of damages and losses.

Until now, the vulnerability of roads and has not been much noticed. Road and bridge maintenance plans were undertaken only based on a regular survey, not focused on disaster risk indicators of road and bridge elements.

To be able to assess the vulnerability of an element to a particular hazard, it can be seen from a study that describes the extent of damage of an element at a certain level of hazard that is expressed in the form of a fragility curve [6].

To define the vulnerability of road segments should be considered from the various components of bridges, embankments, tunnels, and others with different vulnerability characteristics and are not always comparable. Some elements of the road network components that are rated vulnerability are bridges. Vulnerability assessment is conducted by considering design criteria of earthquake loads, continuous or noncontinuous construction types, foundation soil conditions, construction maintenance conditions, alignment, and others.

Reference [7] describe a risk analysis based on Geographic Information System (GIS). This risk analysis consists of 3 (three) main components, i.e., geographical data in GIS, land movement attenuation model, and risk model that can predict the degree of bridge degradation due to the intensity of specific ground motion at the location. Reference [8] developed seismic risk analysis (SRA) on highway systems. The methodology used can be applied multidisciplinary and use the vulnerability of the bridge as one of the inputs. Vulnerability assessment on roads and bridges to earthquakes was also carried out by [9] in Kathmandu, Nepal. This study was conducted by comparing several vulnerability methods used by
JICA, RADIUS, and HAZUS. Roads and bridges are grouped into specific categories and scenarios of earthquakes, so that road and bridge vulnerability in the study area can be identified through vulnerability criteria for roads and bridges. In the method developed by JICA, roads are grouped into several groups of road status from national road to regional roads as well as inner city and outer city ring roads. In this method, the vulnerability of the road is viewed from the probability of the landslide, not the road structure.

Risk assessments on the road network are described as hazard $\mathrm{x}$ vulnerability and exposure of linkages between road networks. To illustrate the magnitude of each exposure element, hazard and vulnerability are described by the equation below [10]:

$$
\begin{gathered}
\text { Damage }=X_{\mathrm{PGA}} \times V \\
\text { Risk }=\text { Exposure } \times \text { Damage }
\end{gathered}
$$

$$
\begin{aligned}
& \text { Where: } \\
& \begin{array}{ll}
X_{\mathrm{PGA}} & =\text { Peak Ground Acceleration in the hazard index } \\
V & =\text { vulnerability }
\end{array}
\end{aligned}
$$

\section{Methodology}

Vulnerability factor is one of the risk factors that contribute to risk. This study was conducted by identifying vulnerability indicators from several previous studies. The development and modification, indicators that affect the vulnerability factor of the earthquake risk assessment model for the road performed.

Risk index assessment model used in this study. The risk index model is the most appropriate model used nowadays considering data completeness and ease of use of the model. Risk index model adopted from the Earthquake Disaster Risk Index (EDRI) developed by [11]. EDRI used for several big cities in the world.

\subsection{Identification of indicators}

The vulnerability is a factor affecting disaster risk. The higher the vulnerability, the higher the risk of disaster. The identified vulnerability factors are divided into components of the physical vulnerability and population susceptibility factors [11]. Components of physical vulnerability factors in a city that consider characteristics to reduce vulnerability through the use of a seismic code, city-owned resources, city age, population density, and speed of urban development. The vulnerability of the population in question is the vulnerability of the population in one city that will be more difficult to escape from the collapse of the building in the event of a disaster, given the model is used for the scope of the city. Indicators of the vulnerability factor component of this population are population aged less than 4 years, or more than 65 years.

In the vulnerability factor identified by [10], the factor component that influences only the components of the physical vulnerability factor, considering the element 
at risk in the model is the road segment. The components of the physical vulnerability show more components of the factors directly related to disaster risk on the road.

In addition to a physical vulnerability, components of the economic vulnerability factor also affect disaster risk. In the concept of road vulnerability analyzed [9] the economic vulnerability of one road segment is shown by the function and importance of the road segment in the road network.

\subsection{Selection of indicators}

Criteria for the selection of indicators are as follow: valid, reliable, data availability, objective, can be quantified, and directly influence the risk.

\subsection{Indicators' weight}

The analysis was performed to obtain the weight of influence or contribution of each indicator to assess the risk of the earthquake. In this study, the analytic hierarchy process (AHP) is used. The questionnaire is used to get the weights needed for each indicator. Respondents were selected from several agencies who were disaster experts and had more than 10 years of experience in disaster studies.

\section{Result}

From the identification of previous studies, the components factor of vulnerability factor is the physical vulnerability and economic vulnerability.

\subsection{Physical vulnerability}

The components of the physical vulnerability factor are described as the degree of direct damage that can occur to roads and bridges caused by the particular degree of earthquake hazard. In general, the level of damage can be assessed in the damage ratio is repair costs due to damage. The structural vulnerability can be assessed from the damage curve or the fragility curve. For roads and bridges in Indonesia, no damage curves or fragility curves are available. The ability of one structure to survive from the earthquake will depend on structural systems and construction materials, configurations, structural continuity, changes in structural conditions from the beginning of construction used, a distance of construction to other construction, and redundancy of the network [11]. For the scope of the road segment, it can be assessed in the number of bridges and other critical structural elements [12]. Bridges and other critical structural elements such as tunnels can be a weak element of the road because there may be damage to the bridge and other structural elements due to earthquakes because they have different structures with roads directly above the ground (at grade). Construction of elevated bridges has a higher vulnerability than road construction that is directly above the ground (at grade).

In addition, the percentage of long-span bridges can affect the vulnerability of one road segment [10]. Long span bridges have a higher vulnerability compared to standard span bridges. The longer the main span of the bridge, the shake of the bridge structure due to the earthquake will be more fabulous. The higher the structural wobble that occurs, the possibility of structural failure will be higher. Long span bridge in Indonesia is a bridge with a main span length of at least 150 meters.

Another indicator that can be used to assess physical vulnerability is the existing condition of the bridge ([10]. The existing condition of the bridge is very influential on the risk due to the disaster. The existing condition of the bridge can be assessed from the bridge performance assessment resulting from an assessment of the Bridge Management System implemented in Indonesia. The better the condition of one bridge, the less risk of physical vulnerability will be less. The condition of the bridge will be related to how the bridge structure will withstand the earthquake load that occurred. The better the bridge structure, the lower the physical vulnerability of the bridge.

Another indicator that can be used to assess physical vulnerability is the age of construction ([9]. The older age of construction will affect the vulnerability of construction to earthquake hazards. This is influenced by the seismic code that applies when construction is designed and implemented. The seismic code sets the conditions for designing construction according to the current hazard conditions.

Topographic indicators are among the indicators that affect the physical vulnerability of construction [9][10]. Road construction carried out on lowland with a relatively small slope, from the implementation side has a small difficulty level. Construction is more accessible to perform on the relatively flat terrain. In the construction that is in the hills or mountains, the difficulty of construction implementation is higher. With the inclination of terrain on the construction in the hills/mountains will have difficulty in the implementation of construction. In the construction that is in the hills/mountains should be cutting hills/mountains. This construction is more likely to have difficulties in compacting the construction and the challenges of roadside slopes/slopes. Incompressible compaction makes road construction more vulnerable to earthquake hazards.

The soil type indicator is one of the indicators of physical vulnerability on the road. Soil types have contributed to the risks of earthquakes. The loose soil type will have a higher vulnerability than a cohesive soil road construction [9]. Although the replacement of the soil in the construction and the compacting process, the type of soil continues to contribute to the vulnerability of construction.

The essential soil condition of the construction which is a dug or heap is another indicator that may affect the vulnerability of the construction. Construction on the embankment has a higher vulnerability than that of the original soil or excavated soil [9][10].

Another potential indicator of the vulnerability is the availability of alternative routes [10]. The availability of alternative routes will be closely related to network redundancies. The more alternative routes that road users 
can use if one road segment is disrupted by a disaster, the lower the level of physical vulnerability. In a study conducted by [9] other indicators used to assess the physical vulnerability of one road segment is the distance of the building, especially the multi-storey building (more than 3 floors) located around the road to the road infrastructure can increase disaster risk due to earthquake with the consideration that a collapse of a building on the road can affect the function of the road. The more and more densely packed buildings around or on the side of the road will increase the risk.

\subsection{Economy vulnerability}

The economic vulnerability of road segment illustrates how much economic disturbance will occur in accordance with the level of earthquake hazard that occurs. Economic vulnerability is related to the indirect losses incurred due to physical damage from roads and bridges that will be heavily dependent on the function and status of the road. Damage to one segment of the road can disrupt the economy and affect the productivity of many sectors. The higher the value of function and importance level in the status of one segment of the road within the then the vulnerability of the road segment will be higher [9]. This indicator is not used in this study, due to research limits only for national road segments. If the model is used for all types of function and road status, then this indicator can be used.

From the results of questionnaires and interviews that were collected, the analysis was done with the help of Expert choice software. This software helps in performing the weighting of the respondents by the number of lots. Each answer of the respondents will be processed by pairwise so we get the weight by comparing indicators in one level of factor components. Each of the analyzed answers will be selected for a consistency level of not more than 0.25 . This is to avoid a much different value from one indicator with another. In addition, it will result in the merging analysis between respondents will be much different.

Table 1. Indicators and weights.

\begin{tabular}{|c|c|}
\hline Indicator & Weight \\
\hline Number of Bridges & 0.11 \\
\hline Percentage of long-span bridges & 0.1 \\
\hline Bridge's condition & 0.14 \\
\hline Construction's age & 0.11 \\
\hline Road's condition & 0.08 \\
\hline Topography & 0.1 \\
\hline Type of soil & 0.13 \\
\hline Cut/fill road's construction & 0.11 \\
\hline Availability of alternative routes & 0.12 \\
\hline
\end{tabular}

Type of soil is the most influenced indicator of the risk. Because many indicators are selected and used, there is no dominant indicator in this physical vulnerability.

\subsection{Score of Indicators}

Each of the indicators classified into 5 (five) level. Each level describes how it influences the vulnerability. The score of each indicator shown in these tables below.

Table 2. Classification and score of a number of bridges.

\begin{tabular}{|c|c|c|}
\hline Number of Bridge & Class & Score \\
\hline 1 bridge, length $<2 \mathrm{~m}$ & Very low & 1 \\
\hline $\begin{array}{c}1 \text { or 2 bridges, @max length 10 } \\
\mathrm{m}\end{array}$ & Low & 2 \\
\hline 1 or 2 bridges, @length 10-20 m & Moderate & 3 \\
\hline 2 bridges, @length $>20 \mathrm{~m}$ & High & 4 \\
\hline $\begin{array}{c}\text { More than 2 bridges, length }>20 \\
\mathrm{~m}\end{array}$ & Very high & 5 \\
\hline
\end{tabular}

Table 3. The percentage of long span bridge.

\begin{tabular}{|c|c|c|}
\hline \% Long span bridge & Class & Score \\
\hline $1-2 \%$ & Very low & 1 \\
\hline $2-5 \%$ & Low & 2 \\
\hline $5-10 \%$ & Moderate & 3 \\
\hline $10-15 \%$ & High & 4 \\
\hline$>15 \%$ & Very high & 5 \\
\hline
\end{tabular}

Table 4. The condition of the bridge.

\begin{tabular}{|c|c|c|}
\hline $\begin{array}{c}\text { Condition of } \\
\text { Bridge }\end{array}$ & Class & Score \\
\hline $\begin{array}{c}\text { Very good, no } \\
\text { damage, } \\
\text { condition's rate 0, } \\
\text { smooth traffic }\end{array}$ & $\begin{array}{c}\text { Very } \\
\text { low }\end{array}$ & 1 \\
\hline $\begin{array}{c}\text { Good, minor } \\
\text { damage, } \\
\text { condition's rate 1, } \\
\text { smooth traffic }\end{array}$ & Low & 2 \\
\hline $\begin{array}{c}\text { Moderate, } \\
\text { moderate damages, } \\
\text { condition's rate 2, } \\
\text { smooth traffic }\end{array}$ & Mode \\
\hline $\begin{array}{c}\text { Moderate, } \\
\text { moderate damages, } \\
\text { condition's rate 3, } \\
\text { quite smoothly } \\
\text { traffic }\end{array}$ & High & 3 \\
\hline $\begin{array}{c}\text { Poor, major } \\
\text { damage, } \\
\text { condition's rate 4 - } \\
\text { 5, disturbed traffic }\end{array}$ & Very \\
high & 5 \\
\hline
\end{tabular}


Table 5. Age of road construction.

\begin{tabular}{|c|c|c|}
\hline Road construction's age & Class & Score \\
\hline$<2$ year & Very low & 1 \\
\hline 2- 6 year & Low & 2 \\
\hline 6-14 year & Moderate & 3 \\
\hline 15-30 year & High & 4 \\
\hline$>30$ year & Very high & 5 \\
\hline
\end{tabular}

Table 6. The condition of the road.

\begin{tabular}{|c|c|c|}
\hline Road's condition & Class & Score \\
\hline Very good, no damage & Very low & 1 \\
\hline $\begin{array}{c}\text { good, \% damage to surface } \\
\text { pavement surface area }<6 \% \text { for } \\
\text { asphalt/concrete, }<11 \% \text { no surface } \\
\text { cover }\end{array}$ & Low & 2 \\
\hline $\begin{array}{c}\text { Moderate, } \% \text { damage to surface } \\
\text { pavement surface area } 6-11 \% \text { for } \\
\text { asphalt/concrete, } 11-16 \% \text { no } \\
\text { surface cover }\end{array}$ & Moderate & 3 \\
\hline $\begin{array}{c}\text { Minor damage, } \% \text { damage to } \\
\text { surface pavement surface area } 11- \\
15 \% \text { for asphalt/concrete, } 16-23 \% \\
\text { no surface cover }\end{array}$ & High & 4 \\
\hline $\begin{array}{c}\text { Major damage, } \% \text { damage to } \\
\text { surface pavement surface area } \\
>15 \% \text { for asphalt/concrete, } 23 \% \\
\text { no surface cover }\end{array}$ & Very high & 5 \\
\hline
\end{tabular}

Table 7. Topography.

\begin{tabular}{|c|c|c|}
\hline Topography & Class & Score \\
\hline Lowlands, slope $<3 \%$ & Very low & 1 \\
\hline Lowlands, slope 3-10 & Low & 2 \\
\hline Hilly area, slope $11-18 \%$ & Moderate & 3 \\
\hline Hilly area, slope $18-25 \%$ & High & 4 \\
\hline Mountain area, slope $>25 \%$ & Very high & 5 \\
\hline
\end{tabular}

Each score of the indicator will be multiplied by their own weight. The result will describe vulnerability index of each road segment. The higher the vulnerability index is obtained, the priority to the road segment should be increased.
Table 8. Type of soil.

\begin{tabular}{|c|c|c|}
\hline Type of Soil & Class & Score \\
\hline Very cohesive soil & Very low & 1 \\
\hline Cohesive Soil & Low & 2 \\
\hline Medium cohesive soil & Moderate & 3 \\
\hline Loose soil & High & 4 \\
\hline Very loose soil/ sandy soil/ soft & Very high & 5 \\
\hline
\end{tabular}

Table 9. Base soil condition.

\begin{tabular}{|c|c|c|}
\hline Base soil condition & Class & Score \\
\hline $\begin{array}{c}\text { Original land without pit or pile, } \\
\text { on the side of the road there are } \\
\text { no slopes }\end{array}$ & Very low & 1 \\
\hline $\begin{array}{c}75 \% \text { of the excavated land, on } \\
\text { the side of the road there are no } \\
\text { slopes }\end{array}$ & Low & 2 \\
\hline $\begin{array}{c}50 \% \text { of the excavated land, on } \\
\text { the side of the road there is one } \\
\text { slope }\end{array}$ & Moderate & 3 \\
\hline $\begin{array}{c}75 \% \text { embankment, on the side of } \\
\text { the road there is one slope }\end{array}$ & High & 4 \\
\hline $\begin{array}{c}\text { Embankment, on the side of the } \\
\text { road there is one slope }\end{array}$ & Very high & 5 \\
\hline
\end{tabular}

Table 10. Availability of alternatives route.

\begin{tabular}{|c|c|c|}
\hline $\begin{array}{c}\text { Availability of Alternative } \\
\text { Route }\end{array}$ & Class & Score \\
\hline $\begin{array}{c}\text { There are more than 1 } \\
\text { alternative routes available with } \\
\text { the same class }\end{array}$ & Very low & 1 \\
\hline $\begin{array}{c}\text { More than one alternative route } \\
\text { is available, one alternative has } \\
\text { the same class and function }\end{array}$ & Low & 2 \\
\hline $\begin{array}{c}\text { Available only 1 alternative } \\
\text { route, lower class and function } \\
\text { road, relatively same distance }\end{array}$ & Moderate & 3 \\
$\begin{array}{c}\text { There is 1 alternative route, } \\
\text { lower class and function of the } \\
\text { road, the distance is 1.5 times } \\
\text { the normal route }\end{array}$ & High & 4 \\
\hline There is no alternative route & Very high & 5 \\
\hline
\end{tabular}

\section{Conclusions}

There is two component factor, physical vulnerability economic vulnerability identified for vulnerability factor in this study. Considering the direct impact on risks and limitations on this study for national roads, only physical vulnerability is used.

There are 9 indicators identified and can be used in this vulnerability factor. They are a number of bridges, the percentage of long-span bridges, the condition of the 
bridge, the age of road construction, the condition of the road, topography, type of soil, base soil condition, and availability of alternatives routes. Each indicator has a score that can be used to calculate the index of vulnerability. Each score will be multiplied by the weight of indicator. The higher vulnerability index of the road, it should has more attention and more priority to get.

\section{References}

1. Ministry of Public Work and Housing, Banda Aceh National Road Implementation Center I, Central Aceh Earthquake Report (7 Desember 2016) (2016)

2. B. Wisner, P. Blaikie,., T. Canon, and I. Davis. At risk, Natural hazards, People's vulnerability and disasters (Taylor and Francis Group, 1994)

3. United Nations International Strategy for Disaster Reduction. [Online]. Available: https://www.unisdr.org/we/inform/publications/7817. (2009)

4. D. P, Coppola, Introduction to international disaster management. 2nd Edition (Elsevier Inc, 2011)

5. A. Coburn, and R. Spence, Earthquake protection. (John Wiley \& Sons. West Sussex, 2002)

6. I W. Sengara and K. S. Pribadi. Risk assessment for earthquake prevention and mitigation in Indonesia. Managing disaster risk at the Indonesian Maritime State; Efforts to reduce disaster risk. (Bandung Institute of Technology, Bandung, 2009)

7. S.A. King, and A. S. Kiremidjian. Regional seismic hazard and risk analysis through geographic information systems, The John A. Blume Earthquake Engineering Centre. Report no. 111. (Stanford University, California, 1994)

8. S.D. Werner, S. Cho, R.T. Eguchi. Analysis of risk to Southern California highway system. The ShakeOut Scenario, (USGS Report 2008-1150. Oakland, CA, 2008)

9. P. T. Tung. Road vulnerability assessment for earthquakes, A case study of Lalitpur, KathmanduNepal," M. Eng. Thesis. (International Institute for Geo-Information Science and Earth Observation. Enschede, Netherlands, 2004)

10. S. Cafiso, Assessment of seismic risk and reliability of road network. [Online]. Available: http://cdn.intechopen.com/pdfs/11745/InTech(2010)

11. R. A. Davidson. An urban earthquake disaster risk index," The John A. Blume Earthquake Engineering Centre. Report no. 121. (Stanford University, California, 1997)

12. M. Hosseini, F.Y. Vayeghan. Risk management model for inter-city road systems. The 14th World Conference on Earthquake Engineering. (Beijing, China, 2008). 